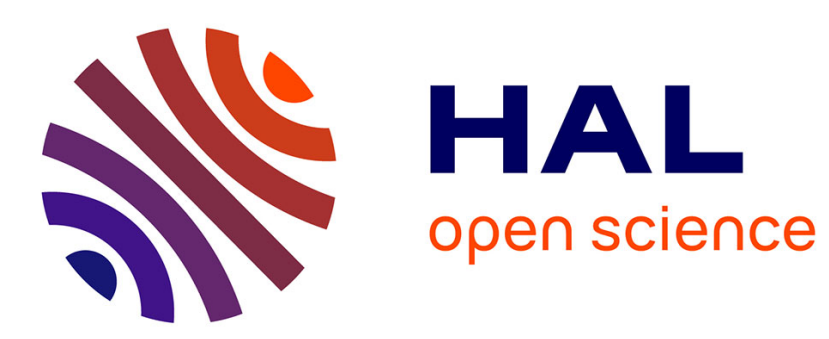

\title{
Financial versus strategic bidders: Evidence from unsuccessful takeover bids
}

\author{
Magnus Blomkvist, Timo Korkeamäki
}

\section{To cite this version:}

Magnus Blomkvist, Timo Korkeamäki. Financial versus strategic bidders: Evidence from unsuccessful takeover bids. Economics Letters, 2017, 159, pp.142-144. 10.1016/j.econlet.2017.07.034 . hal01578935

\section{HAL Id: hal-01578935 \\ https://hal-audencia.archives-ouvertes.fr/hal-01578935}

Submitted on 30 Aug 2017

HAL is a multi-disciplinary open access archive for the deposit and dissemination of scientific research documents, whether they are published or not. The documents may come from teaching and research institutions in France or abroad, or from public or private research centers.
L'archive ouverte pluridisciplinaire HAL, est destinée au dépôt et à la diffusion de documents scientifiques de niveau recherche, publiés ou non, émanant des établissements d'enseignement et de recherche français ou étrangers, des laboratoires publics ou privés. 


\title{
Financial versus Strategic Bidders:
}

\section{Evidence from Unsuccessful Takeover Bids}

\author{
Magnus Blomkvist ${ }^{1}$ \\ Audencia Business School - Nantes \\ mblomkvist@audencia.com \\ Timo Korkeamäki \\ Hanken School of Economics \\ timo.korkeamaki@hanken.fi
}

\begin{abstract}
:
Even failed takeovers can identify undervalued target firms. We find that compared to financial bidders, strategic buyers have a greater lasting valuation effect on the targets. Strategic bidders thus appear to be superior in identifying undervalued targets.
\end{abstract}

JEL Classification: G30, G32, G34

Keywords: Mergers and Acquisitions; Corporate Investments; Private Equity

\footnotetext{
${ }^{1}$ Corresponding author: Magnus Blomkvist, Audencia Business School - Nantes, 8 Route de la Jonelière, 44312 Nantes, France, +33785632514, mblomkvist@ audencia.com.
} 


\section{Introduction}

While corporate finance practitioners commonly distinguish between financial and strategic buyers in M\&A transactions, only few empirical academic studies on differences between them exist. Exceptions include Martos-Vila, et al. (2012), who report that fluctuation in acquisition activity takes different patterns between the two buyer types, with the level of activity by financial acquirers being driven by debt market conditions, and Bargeron, et al. (2008), who find that strategic buyers tend to pay a higher premium for their targets.

Through their expertise in business valuation and operational improvements, financial buyers can identify undervalued targets and generate value for the target firm (Gorbenko and Malenko, 2014). On the other hand, strategic buyers tend to be motivated by potential synergies, while they may also possess expertise in valuation within their own industry (Rhodes-Kropf, et al., 2004, 2005; Malmendier, et al., 2016; Vild and Zeisberger, 2013).

We study unsuccessful takeover attempts. The setting allows us to observe whether a proposed takeover has a lasting valuation impact, and whether that impact varies by acquirer type. Takeover announcements are typically met by a positive stock reaction, but if that reaction rests on buyer-specific characteristics such as expected synergy benefits, the extra value should vanish upon cancellation of the deal (Bradley, et al., 1983). If, on the other hand, the bidder has simply identified an undervalued target, the bid should send a signal of that undervaluation to the market, and the valuation effect should be more permanent. Since synergies are more likely to motivate strategic bids, our main hypothesis is that the lasting value effect of financial bids is greater.

\section{Data and Research Design}


Our data on acquisition transactions come from the SDC platinum. Our sample includes failed U.S. transactions, with the announcement date between 1.1.1990 and 31.12.2013. We require the target firm to be covered by CRSP and COMPUSTAT, and the acquisition needs to concern at least $51 \%$ of the target firm. We exclude bids that target either financial institutions (SIC code 6000-6999) or utilities (SIC code 4000-4999). We follow Malmendier, et al. (2016), and exclude transactions where the time-lapse between the announcement and the failure is either below 5 days or over 365 days. To make the bids comparable, we only consider $100 \%$ cash bids. With these parameters, we end up with a sample of 242 failed takeover attempts. We categorize financial buyers as having SIC code $6799^{2}(\mathrm{~N}=115)$, while other acquirers are categorized as strategic $(\mathrm{N}=127)$.

Our empirical set up and choice of specifications follow closely those in Malmendier, et al. (2016), who also study failed merger attempts. We calculate the abnormal returns using an event window from twenty-five days prior to the bid announcement until twenty-five days after the failure of the bid. We control for target characteristics that may affect information revelation in the bid. Those characteristics include size (ln(sales)), intangible assets/total assets, EBITDA/total assets, and Tobin's q, proxied by (total assets-total equity + market capitalization)/total assets. We also control for the number of days between the bid and the rejection (ln(days)), for the premium offered in relation to the share price 4 weeks prior to the bid. Finally, we include indicators for bids/deals that include a toehold, a termination fee, contested bids and for bids that are hostile, as indicated by the SDC.

Takeover failures can often be followed, or even instigated, by a competing offer. We consider existence of competing bidders in our research design. Since financial buyers use predominantly cash as currency when conducting acquisitions, we limit our sample to cash

\footnotetext{
${ }^{2}$ The SIC code is referred to as "Investors, not elsewhere classified". The classification includes Private Equity and Venture Capital firms.
} 
deals among strategic bids as well, as differences between cash and equity deals are welldocumented (Fishman, 1989; Shleifer and Vishny, 2003; and many others).

Deal failures are not exogenous events. It is possible that the reason for failure affects the returns. However, Malmendier et al. (2016) report that the only reported reason for failure that yields results that stand out from the rest of the sample is market wide shocks such as "September 11" and the "Sub-prime crisis". In our regressions, we use clustering and employ industry x year-, industry-, and year-fixed effects, which should alleviate the concern that failures that are instigated by market wide shocks drive our results.

\section{Results}

Since the time between the bid and the failure of the deal varies among our observations, we follow Malmendier, et al. (2016) and normalize the period between the two events to 50 days. Figure 1 shows a linear approximation of the mean CAR, constructed using synthetic 50 days between the bid and the failure, by acquirer type. There is a clear difference between strategic and financial bids. Somewhat surprisingly, strategic bids are met by a more positive initial reaction, and they also exhibit a greater sustained value effect. Figure 1 thus suggests that industrial buyers are better in identifying undervalued targets.

We further compare financial and strategic bids in Table 1. The average CAR from twentyfive days before bid to twenty-five days after failure is $17.7 \%$ for strategic bidders, versus $2.4 \%$ for financial bidders. The two groups exhibit also a slight deviation in ROA, Toehold, time between the bid and the failure, and frequency of hostile bids. All these covariates will be among the control variables in our regression analysis.

In Table 2, we run six different regression specifications. In the first three specifications we include all cash bids and control for the existence of multiple bidders. In specifications (3) - 
(6), we follow Malmendier et al. (2016) and only include targets with a single bidder, according to the SDC. The types of fixed effects vary by each column, as indicated. ${ }^{3}$ Consistent with Figure 1 and Table 1, financial bidders are connected to lower CARs in all Table 2 specifications. The negative effect of financial bidders on CARs is slightly greater and statistically stronger in specifications where only deals with a single bidder are included. Our control variables behave consistently across specifications, but their statistical significance varies. In line with Malmendier et al. (2016) the offer premium has a positive effect on the CAR.

In summary, our results indicate that an acquisition attempt by a strategic bidder generates a target firm revaluation that is more positive than that connected to a financial bid attempt. This finding suggests that strategic bidders have a superior ability to find undervalued targets.

\section{Conclusion}

We explore the undervaluation channel for value creation in financial and strategic M\&A by measuring the revaluation of failed bids. We find that the undervaluation channel for takeover returns is relatively more important for strategic buyers. The target's revaluation following a failed bid is about $20 \%$ greater for strategic targets.

\footnotetext{
${ }^{3}$ We vary clustering of standard errors to match the type of fixed effects in each column.
} 


\section{References}

Bradley M., Desai A., Kim E.H., 1983, The Rationale behind Interfirm Tender OffersInformation or synergy?, Journal of Financial Economics 11, 183-206.

Bargeron L.L., Schlingemann F.P.,Stulz R.M., Zutter C.J., Why do private acquirers pay so little compared to public acquirers?, Journal of Financial Economics, 89, 375-390.

Gorbenko A.S., Malenko A., 2014, Strategic and Financial Bidders in Takeover Auctions, Journal of Finance, 69, 2513-2555.

Malmendier U, Opp M, Saidi F., 2016, Target revaluation after failed takeover attempts: Cash versus stock, Journal of Financial Economics, 119, 92-106

Martos-Vila M., Rhodes-Kropf M., Harford J.,2013. Financial vs. Strategic Buyers, NBER working paper

Rhodes-Kropf M., Viswanathan S., 2004, Market Valuation and merger waves, Journal of Finance, 63, 1169-1211.

Rhodes-Kropf M., Robinson D., Viswanathan S., 2005, Valuation waves and merger activity: The empirical evidence, Journal of Financial Economics, 77, 551-603.

Vild J., Zeisberger C., 2014, Strategic buyers vs. private equity: buyers in an investment process, INSEAD Working paper 
Figure 1: Graphical Evidence

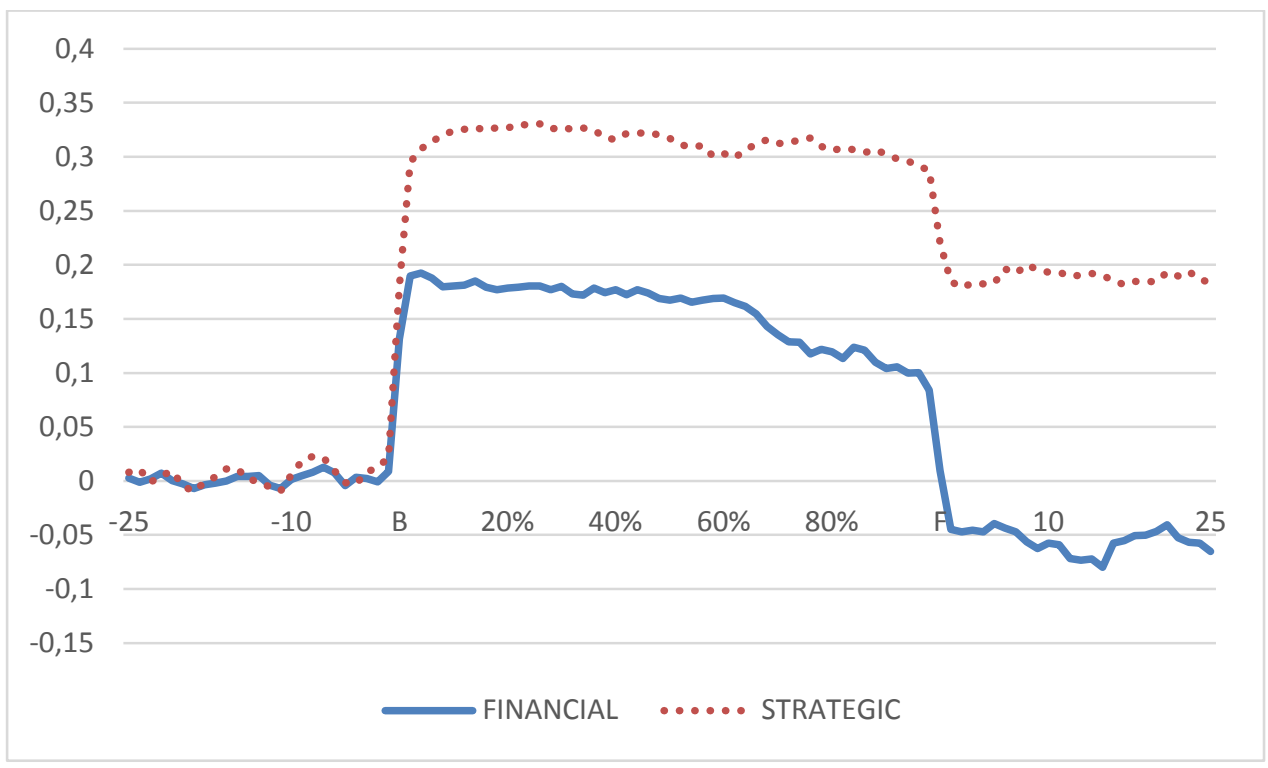


Table 1: Sample characteristics

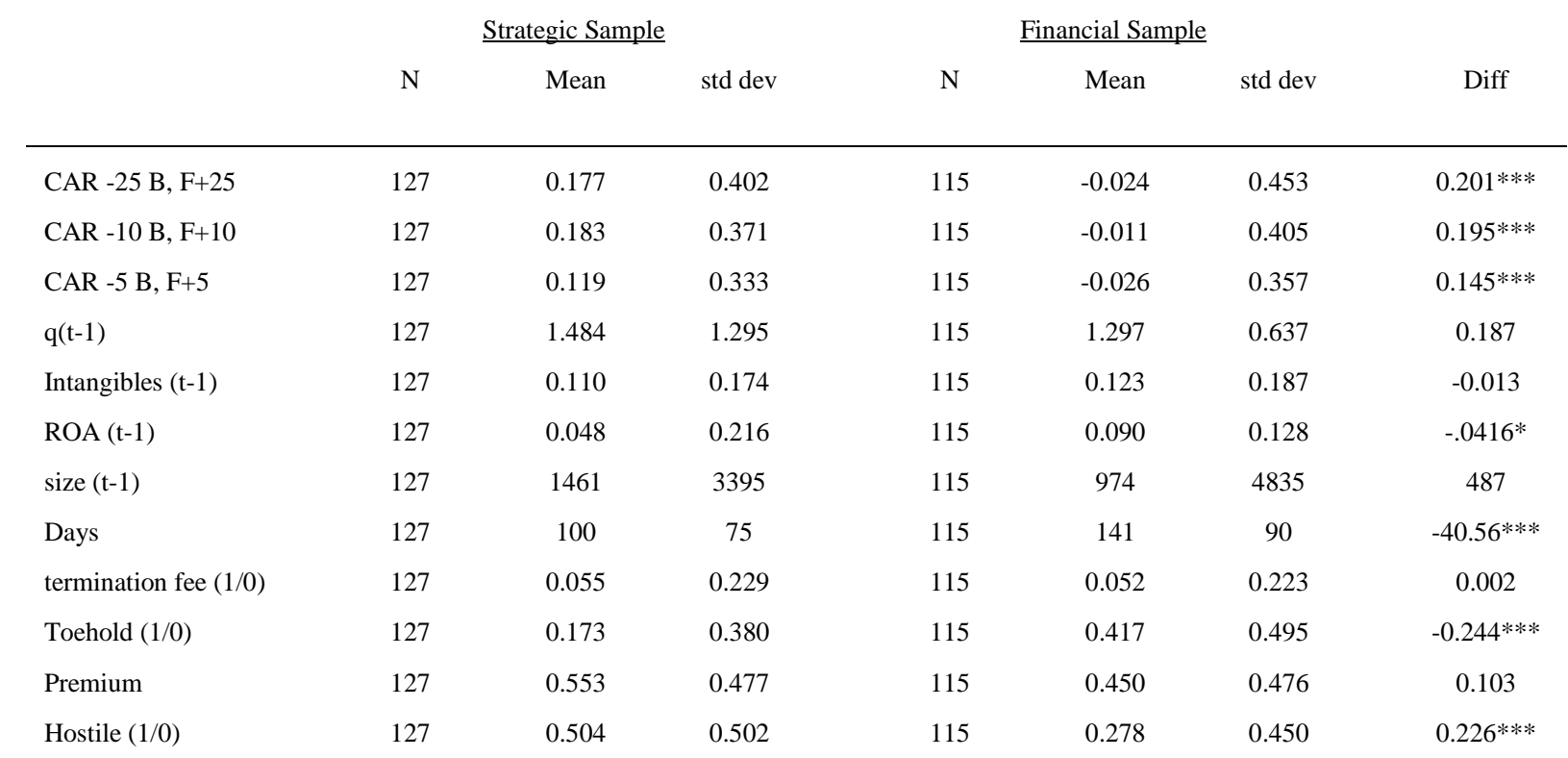

$*, * *, * * *$ denotes statistical significance on $10 \%, 5 \%, 1 \%$ level respectively 
Table 2: Multivariate analysis

\begin{tabular}{|c|c|c|c|c|c|c|}
\hline & $\begin{array}{c}\text { (1) } \\
\text { CAR- } \\
25 \mathrm{~B} / \mathrm{F}+25 \\
\end{array}$ & $\begin{array}{c}(2) \\
\text { CAR- } \\
25 \mathrm{~B} / \mathrm{F}+25 \\
\end{array}$ & $\begin{array}{c}(3) \\
\text { CAR- } \\
25 \mathrm{~B} / \mathrm{F}+25 \\
\end{array}$ & $\begin{array}{c}(4) \\
\text { CAR- } \\
25 \mathrm{~B} / \mathrm{F}+25 \\
\end{array}$ & $\begin{array}{c}(5) \\
\text { CAR- } \\
25 \mathrm{~B} / \mathrm{F}+25 \\
\end{array}$ & $\begin{array}{c}(6) \\
\text { CAR- } \\
25 \mathrm{~B} / \mathrm{F}+25 \\
\end{array}$ \\
\hline \multirow[t]{2}{*}{ Financial bidder } & $-0.202^{*}$ & $-0.208 * * *$ & $-0.235 * * *$ & $-0.225^{* *}$ & $-0.234 * * *$ & $-0.259 * * *$ \\
\hline & $(0.104)$ & $(0.0716)$ & $(0.0701)$ & $(0.103)$ & $(0.0721)$ & $(0.0715)$ \\
\hline \multirow[t]{2}{*}{$\mathrm{q}(\mathrm{t}-1)$} & 0.0785 & 0.0248 & 0.0232 & 0.0618 & 0.0254 & 0.0173 \\
\hline & $(0.0575)$ & $(0.0353)$ & $(0.0349)$ & $(0.0641)$ & $(0.0399)$ & $(0.0371)$ \\
\hline \multirow[t]{2}{*}{ Intangible Assets/Total Assets (t-1) } & $-0.591 * * *$ & -0.0818 & -0.111 & $-0.910 * * *$ & -0.100 & -0.142 \\
\hline & $(0.203)$ & $(0.104)$ & $(0.126)$ & $(0.269)$ & $(0.142)$ & $(0.136)$ \\
\hline \multirow[t]{2}{*}{$\mathrm{ROA}(\mathrm{t}-1)$} & 0.626 & $0.603^{*}$ & $0.620 * * *$ & 0.376 & $0.540 * * *$ & $0.578^{* *}$ \\
\hline & $(0.399)$ & $(0.301)$ & $(0.214)$ & $(0.461)$ & $(0.194)$ & $(0.215)$ \\
\hline \multirow[t]{2}{*}{$\ln ($ sales) (t-1) } & $-0.0682 * *$ & $-0.0459^{* * *}$ & $-0.0328^{*}$ & -0.0337 & -0.0156 & -0.0132 \\
\hline & $(0.0278)$ & $(0.0147)$ & $(0.0161)$ & $(0.0354)$ & $(0.0177)$ & $(0.0203)$ \\
\hline \multirow[t]{2}{*}{$\ln$ (days between bid and failure) } & -0.0550 & -0.0228 & -0.0264 & $-0.163 * * *$ & $-0.0675^{*}$ & -0.0499 \\
\hline & $(0.0464)$ & $(0.0422)$ & $(0.0241)$ & $(0.0604)$ & $(0.0400)$ & $(0.0384)$ \\
\hline \multirow[t]{2}{*}{ Termination fee $(1 / 0)$} & 0.0628 & $-0.162 * *$ & -0.128 & -0.122 & $-0.194 * *$ & -0.140 \\
\hline & $(0.163)$ & $(0.0634)$ & $(0.100)$ & $(0.201)$ & $(0.0768)$ & $(0.142)$ \\
\hline \multirow[t]{2}{*}{ Premium } & $0.195^{*}$ & $0.108^{*}$ & $0.181 * *$ & 0.187 & $0.246 * * *$ & $0.284 * * *$ \\
\hline & $(0.117)$ & $(0.0589)$ & $(0.0831)$ & $(0.137)$ & $(0.0680)$ & $(0.0729)$ \\
\hline \multirow[t]{2}{*}{ Hostile (1/0) } & 0.0663 & 0.0907 & 0.0455 & -0.0498 & 0.0756 & 0.0178 \\
\hline & $(0.125)$ & $(0.0859)$ & $(0.0826)$ & $(0.145)$ & $(0.0724)$ & $(0.0846)$ \\
\hline \multirow[t]{2}{*}{ Toehold (1/0) } & 0.122 & 0.134 & 0.113 & 0.108 & 0.0623 & 0.0682 \\
\hline & $(0.107)$ & $(0.0891)$ & $(0.0734)$ & $(0.120)$ & $(0.0746)$ & $(0.0834)$ \\
\hline \multirow[t]{2}{*}{ Contested (1/0) } & -0.199 & 0.0648 & 0.0963 & & & \\
\hline & $(0.167)$ & $(0.0751)$ & $(0.0637)$ & & & \\
\hline \multirow[t]{2}{*}{ Constant } & $0.585^{* *}$ & 0.333 & $0.274 * *$ & $0.986^{* * *}$ & 0.338 & 0.272 \\
\hline & $(0.296)$ & $(0.275)$ & $(0.128)$ & $(0.362)$ & $(0.233)$ & $(0.176)$ \\
\hline Observations & 242 & 242 & 242 & 196 & 196 & 196 \\
\hline $\mathrm{R}$-squared & 0.284 & 0.185 & 0.191 & 0.419 & 0.254 & 0.233 \\
\hline Only 1 bidder & NO & NO & NO & YES & YES & YES \\
\hline TARGET SIC 2 x YEAR FE & YES & NO & NO & YES & NO & NO \\
\hline TARGET SIC2 FE & NO & YES & NO & NO & YES & NO \\
\hline YEAR FE & NO & NO & YES & NO & NO & YES \\
\hline
\end{tabular}

$*, * *, * * *$ denotes statistical significance on $10 \%, 5 \%, 1 \%$ level respectively

Clustered robust standard errors are given in parentheses. 